\title{
Clinical and radiographic features of HIV-related pulmonary tuberculosis according to the level of immunosuppression
}

\author{
Características clínicas e radiológicas da tuberculose pulmonar associada \\ ao HIV de acordo com o nível de imunossupressão
}

\author{
Guilherme Freire Garcia $^{1,2}$, Alexandre Sampaio Moura ${ }^{1,2}$, Cid Sérgio Ferreira ${ }^{2}$ \\ and Manoel Otávio da Costa Rocha ${ }^{2}$
}

\begin{abstract}
Medical charts and radiographs from 38 HIV-infected patients with positive cultures for Mycobacterium tuberculosis from sputum or bronchoalveolar lavage were reviewed in order to compare the clinical, radiographic, and sputum bacilloscopy characteristics of HIV-infected patients with pulmonary tuberculosis according to CD4+ lymphocyte count (CD4). The mean age of the patients was 32 years and $76 \%$ were male. The median CD4was 106 cells $/ \mathrm{mm}^{3}$ and $71 \%$ had CD4 <200 cells $/ \mathrm{mm}^{3}$. Sputum bacilloscopy was positive in $45 \%$ of the patients. Patients with CD 4200 cells $/ \mathrm{mm}^{3}$ showed significantly less post-primary pattern $(7 \%$ vs. 63\%; $p=0.02)$ and more frequently reported weight loss $(p=0.04)$. Although not statistically significant, patients with lower CD4 showed lower positivity of sputum bacilloscopy (37\% vs. 64\%; $p=0.18)$. HIV-infected patients with culture-confirmed pulmonary tuberculosis had a high proportion of non-post-primary pattern in thoracic radiographs. Patients with CD4 lower than 200 cells/ $\mathrm{mm}^{3}$ showed post-primary patterns less frequently and reported weight loss more frequently.
\end{abstract}

Key-words: Pulmonary tuberculosis. Acquired immunodeficiency syndrome. Thoracic radiography. CD4 lymphocyte count.

\section{RESUMO}

Foram revisados prontuários e radiografias de 38 pacientes infectados pelo HIV com culturas de escarro ou lavado broncoalveolar positivas para Mycobacterium tuberculosis no intuito de comparar características clínicas, radiológicas e baciloscópicas de pacientes HIV-positivos com tuberculose pulmonar de acordo com a contagem de linfócitos CD4. A idade média dos pacientes foi 32 anos e $76 \%$ eram homens. Mediana de CD4 foi 106 cells $/ \mathrm{mm}^{3}$ e $71 \%$ tinham CD4 $<200 \mathrm{cel} / \mathrm{mm}^{3}$. Baciloscopia de escarro foi positiva em $45 \%$. Pacientes com $\mathrm{CD} 4<200 \mathrm{cel} / \mathrm{mm}^{3}$ apresentaram significativamente menos padrão pós-primário $(p=0,02)$ e relataram emagrecimento mais freqüentemente $(p=0,04)$. Embora sem significância estatística, pacientes com contagem mais baixa de CD4 apresentaram menor positividade na baciloscopia de escarro $(p=0,18)$. Pacientes HIV-positivos com tuberculose pulmonar confirmada por cultura apresentam alta proporção de padrão diferentes do pós-primário na radiografia torácica. Pacientes com CD4 abaixo de 200 cells $/ \mathrm{mm}^{3}$ apresentaram menos freqüentemente padrão pós-primário e maior proporção relatou perda de peso.

Palavras-chaves: Tuberculose pulmonar. Síndrome da imunodeficiência adquirida. Radiografia torácica. Contagem de linfócito CD4.

It has been estimated that a third of the world's population is infected with Mycobacterium tuberculosis and that $9 \%$ of these cases are associated with human immunodeficiency virus (HIV) infection ${ }^{6}$. The proportion of this association appears to be greater in Africa, but some developed countries, like the USA, also present high numbers ${ }^{6}$. In developing countries, tuberculosis is the leading cause of preventable death ${ }^{6}$, such that it is responsible for approximately $11 \%$ of deaths in adults. Brazil is on the list of the 22 countries that concentrate $80 \%$ of the tuberculosis cases worldwide, occupying the 15 th place in terms of numbers of cases $(114,000$ new cases per year) ${ }^{25}$. In Brazil, HIV infection is responsible for 3.8\% of new cases of tuberculosis in the adult population ${ }^{625}$.

Atypical radiological presentations of pulmonary tuberculosis associated with HIV infection have been described before ${ }^{12122}$, such that HIV-infected patients show a lower frequency of cavitations and higher frequency of mediastinal adenopathy, similar to primary tuberculosis.

The clinical and radiological manifestations of tuberculosis in HIV-infected patients may vary according to the degree of

\footnotetext{
1. Hospital Eduardo de Menezes, Fundação Hospitalar do Estado de Minas Gerais, Belo Horizonte, MG. 2. Programa de Pós-Graduação em Ciências da Saúde: Infectologia e Medicina Tropical, Faculdade de Medicina, Universidade Federal de Minas Gerais, Belo Horizonte, MG.

Address to: Dr. Guilherme Freire Garcia. Av. Brasil 510, sala 205, Santa Efigênia, 30140-001 Belo Horizonte, MG.

Tel: $55313224-1570$

e-mail: guifgarcia@ig.com.br

Recebido para publicação em 24/7/2007

Aceito em 11/10/2007
} 
immunosuppression ${ }^{919}{ }^{20}$, but published data on the subject is still scarce. The objective of the present study was to evaluate the clinical and radiological presentations of culture-confirmed pulmonary tuberculosis in HIV-infected patients.

\section{MATERIAL AND METHODS}

Selection of patients. Inclusion criteria: to be included, patients had to (1) be 13 years of age or older; (2) be HIV-infected according to the CDC (Centers for Disease Control and Prevention) criteria $^{4}$; (3) present a positive culture for Mycobacterium tuberculosis in their sputum or bronchoalveolar lavage; (4) have a record of $\mathrm{CD} 4+\mathrm{T}$ lymphocyte cell counts available for a period of four months before or after the first clinical suspicion of tuberculosis; and (5) have radiographs of the thorax in either posteroanterior or anteroposterior orientation, with or without radiographs in lateral orientations, taken at most 30 days after the first clinical suspicion of tuberculosis.

Exclusion criteria: patients were excluded if (1) their culture for Mycobacterium tuberculosis was not related to a diagnostic procedure but to tuberculosis treatment control, or if (2) they had had a previous pulmonary disease that might be confused with the clinical and radiological patterns of tuberculosis.

Diagnostic tests. The tests used to diagnose HIV were Micro-ELISA AXSYM HIV1/2 (Meia) (Abbott, Abbott Labs, USA) and Western blot (Genelabs Diagnosis Pte Ltd., Singapore). Quantification of HIV RNA was done by measurement of the bDNA (Bayer Diagnostics, USA). CD4+ T-lymphocyte cell counts were assessed using a FACSCalibur flow cytometer (BD Biosciences, USA).

Cutaneous tuberculosis tests were performed in accordance with Brazilian standards using the Mantoux technique of intradermic inoculation of two TUs (tuberculin units) of PPD (purified protein derivative) RT 23. A positive cutaneous reaction was defined as an area of induration $\geq 5 \mathrm{~mm}$ in diameter.

The acid-fast bacillus (AFB) findings from microscopic examination were described in terms of crosses, according to the number of bacilli per microscopic field examined ${ }^{16}$ : (-) negative, when AFB were not found in 100 fields examined; $(+)$ presence of less than one AFB per field in 100 fields examined; $(++)$ presence of one to $10 \mathrm{AFB}$ per field in 50 fields examined; $(+++)$ presence of more than $10 \mathrm{AFB}$ per field in 20 fields examined.

For mycobacterial culturing, Löwenstein-Jensen solid medium was used and growth detection was performed between the $45^{\text {th }}$ and $60^{\text {th }}$ days after specimen inoculation. When growth was detected, speciation of mycobacterial isolates and susceptibility testing followed.

Study design. This was a cross-sectional study, with comparisons of clinical characteristics and radiological data for HIV-infected patients presenting pulmonary tuberculosis, who were classified according to their degree of immunosuppression, as assessed by the CD4+ T-lymphocyte count. The following information was collected from patients' charts: age, sex, race, alcohol consumption, use of steroids, presence of comorbidities (diabetes mellitus, renal failure, cancer or silicosis), risk factors for HIV transmission, signs and symptoms relating to tuberculosis (coughing, fever, expectoration, complaints of significant weight loss or breathing difficulties), tuberculin test results, bacilloscopy results, sputum and bronchoalveolar lavage cultures, previous treatment and/or chemoprophylaxis for tuberculosis infection, CD4+ T-lymphocyte count, use of antiretroviral drugs and tuberculosis as the first opportunistic infection associated with HIV.

Radiological evaluation. Radiographs of the thorax were classified according to post-primary patterns (infusion and/or cavitations in the upper lobes or upper segments of the lower lobes, fibronodular opacities or bronchogenic dissemination) and primary patterns associated with other patterns (miliary pattern, hilar and/or mediastinal lymphadenopathy, pleural effusion, consolidation or localized infiltration in mid or lower-lung fields, lobar consolidation, diffuse reticulonodular infiltration, cavitation in mid or lower-lung fields, nodules or normal radiography) ${ }^{19} 22$. The radiographs of the thorax were evaluated by two of the authors (GFG and $\mathrm{CF}$ ), without previous knowledge of the CD4+ T-lymphocyte count. The level of agreement between the two evaluators for the main radiological patterns was assessed by means of kappa statistics. When evaluations were discordant, the final report was obtained by reaching a consensus between the evaluators.

Statistical analysis. Initially, a descriptive analysis was performed. Some variables did not present a significant number of patients in the groups compared and were presented only in the descriptive statistics. Next, univariate analysis was performed. The variables that presented a significance level of up to 0.25 in the univariate analysis were subjected to multivariate analysis. For the multivariate analysis, $\mathrm{p}$ values $<0.05$ were considered statistically significant. The Epi Info statistical package, version 3.3.2, was used for the analyses.

Ethical matters. The project was approved by the Research Ethics Committee of the Eduardo de Menezes Hospital and also by the Research Ethics Committee of the Federal University of Minas Gerais.

\section{RESULTS}

Of the total of 1,922 mycobacterial cultures examined between September 2000 and July 2004, 34 (1.8\%) were contaminated, 1,308 (68\%) were negative and 580 (30.1\%) were positive, among which 56 (9.6\%) presented non-tuberculosis mycobacterial growth. Of the 524 (90.3\%) positive cultures for Mycobacterium tuberculosis, the material inoculated in 431 (82.2\%) was from sputum and in 26 (4.9\%) was from bronchoalveolar lavage, corresponding to 337 patients. Among these patients, the anti-HIV test was positive in 68 (20.1\%), negative in 99 (29.4\%), inconclusive in 26 (7.7\%), and was not performed in 144 (42.7\%).

Of the 68 patients who were HIV-positive, 38 were included in the study. The other 30 patients were excluded from the study for the following reasons: $22 \mathrm{did}$ not have a $\mathrm{CD} 4+$ T-lymphocyte 
count within the period previously established for inclusion in the study; four did not have a thoracic radiograph in the hospital files; three had radiographs of the thorax which were taken more than 30 days before the first clinical suspicion of tuberculosis; and one presented a radiological image of bronchiectasis, which was considered to be a confounding factor for the radiological diagnosis of tuberculosis.

Descriptive analysis. Of the 38 patients included in the study, 29 (76.3\%) were male and 28 (73.6\%) were nonwhite. The ages of the patients ranged from 22 to 58 years, with a mean age of $32.68 \pm 7.65$ years. The CD $4+$ T-lymphocyte count ranged from one to 558 cells $/ \mathrm{mm}^{3}$, with a mean of 168.5 \pm 172.6 cells $/ \mathrm{mm}^{3}$. Eleven $(28.9 \%)$ patients presented a CD4+ T-lymphocyte count greater or equal to 200 cells $/ \mathrm{mm}^{3}$. Regarding educational levels, $7.9 \%$ were illiterate but most (65.8\%) had concluded elementary school. The vast majority (91.6\%) of the patients were hospitalized. Concerning risk factors for exposure to HIV, no pertinent information was reported in the charts of $42 \%$ of the patients. Exposure through heterosexual contact was described for 15 (39.4\%) patients, followed by homosexual or bisexual contact for three (7.8\%) patients, use of injectable drugs for three (7.8\%) patients and blood transfusion for one patient.

The most common clinical manifestations were coughing and fever, found in $94.7 \%$ of the patients, expectoration in $71 \%$, complaints of significant weight loss in $68.4 \%$ and shortness of breath in 52.6\%. Coughing for a period of less than three weeks was present in 33\% of the patients. Esophageal candidiasis was the most (42\%) common comorbidity.
Patients with higher CD 4 cell counts were significantly older than were patients with lower counts (33 vs. 27 years; $p=0.03$ ) but did not differ in relation to other demographic variables such as gender, race and educational level, nor regarding HAART use or alcohol abuse (Table 1).

Comparison of the clinical manifestations according to the CD4+ T-lymphocyte count showed that those with CD4 cell counts lower than 200 cells $/ \mathrm{mm}^{3}$ did not significantly differ regarding respiratory symptoms or fever (Table 2).

Among the radiological findings, the level of agreement between the two observers, as to the presence of primary and post-primary patterns associated with other patterns was very high (kappa $=0.80$ and 0.78 , respectively). Comparison of the radiological patterns showed that those with higher CD4 cell counts more frequently presented post-primary patterns (63.6 vs $7.4 \%$; $\mathrm{p}=0.02)$. The descriptions of the radiological patterns are shown in Table 3 and indicate that all the patients with CD 4 cell count lower than 200 cells $/ \mathrm{mm}^{3}$ had primary pattern characteristics, especially lymphadenopathy and diffused infiltration.

A greater proportion of the patients with $\mathrm{CD} 4$ cell counts higher than 200 cells $/ \mathrm{mm}^{3}$ had positive findings from AFB microscopy in spontaneous sputum (63.6\% vs. 37.0\%), but the difference was not statistically significant $(\mathrm{p}=0.18)$. The general results from bacilloscopy and mycobacterial culturing are presented in Table 4 and show that only $44 \%$ of the spontaneous sputum samples were positive on $\mathrm{AFB}$ microscopy.

The multivariate analysis of the relationship showed that postprimary patterns and weight loss were significantly associated with CD4 cell count after adjusting for potential confounders (Table 5).

\begin{tabular}{|c|c|c|c|c|c|c|c|}
\hline \multirow[t]{2}{*}{ Variable } & \multicolumn{2}{|c|}{$\mathrm{CD}^{+}>200\left(\mathrm{n}^{0}=11\right)$} & \multicolumn{3}{|c|}{$\mathrm{CD}^{+}<200\left(\mathrm{n}^{\mathrm{0}}=27\right)$} & \multirow[b]{2}{*}{$95 \% \mathrm{CI}$} & \multirow[b]{2}{*}{$\mathrm{p}$} \\
\hline & $\mathrm{n}^{0}$ & $\%$ & $\mathrm{n}^{\underline{0}}$ & $\%$ & $\mathrm{OR}$ & & \\
\hline Male & 8 & 72.2 & 21 & 77.8 & 0.76 & $0.15-3.80$ & 0.74 \\
\hline Non-caucasian & 9 & 81.8 & 19 & 70.4 & 1.90 & $0.33-10.80$ & 0.47 \\
\hline Education $<11$ years & 7 & 63.7 & 21 & 77.8 & 1.84 & $0.47-7.10$ & 0.37 \\
\hline Alcohol use & 2 & 18.1 & 11 & 40.7 & 0.32 & $0.06-1.80$ & 0.20 \\
\hline HAART use & 3 & 27.2 & 7 & 25.9 & 1.07 & $0.22-5.21$ & 0.93 \\
\hline
\end{tabular}

HAART: highly active antiretroviral therapy, OR: odds ratio, CI: confidence interval.

Table 2 - Univariate analysis of clinical parameters among HIV-infected patients with pulmonary tuberculosis, stratified by T CD4 ${ }^{+}$T-lymphocyte count.

\begin{tabular}{|c|c|c|c|c|c|c|c|}
\hline \multirow[t]{2}{*}{ Variable } & \multicolumn{2}{|c|}{$\mathrm{CD}^{+}>200\left(\mathrm{n}^{0}=11\right)$} & \multicolumn{2}{|c|}{$\mathrm{CD}^{+}<200\left(\mathrm{n}^{\mathrm{0}}=27\right)$} & \multirow[b]{2}{*}{$\mathrm{OR}$} & \multirow[b]{2}{*}{$95 \% \mathrm{CI}$} & \multirow[b]{2}{*}{$\mathrm{p}$} \\
\hline & $\mathrm{n}^{0}$ & $\%$ & $\mathrm{n}^{0}$ & $\%$ & & & \\
\hline $\mathrm{Tb}$ as the first $\mathrm{OI}$ & 5 & 45.5 & 7 & 25.9 & 2.38 & $0.55-10.31$ & 0.25 \\
\hline Previous $\mathrm{Tb}$ treatment & 4 & 36.3 & 5 & 18.5 & 2.20 & $0.74-6.60$ & 0.16 \\
\hline Extrapulmonary $\mathrm{Tb}$ & 1 & 9.0 & 7 & 25.9 & 0.29 & $0.03-2.65$ & 0.27 \\
\hline Coughing & 10 & 90.9 & 26 & 96.2 & 0.38 & $0.22-6.76$ & 0.51 \\
\hline Fever & 10 & 90.9 & 26 & 96.2 & 0.83 & $0.15-2.98$ & 0.89 \\
\hline Expectoration & 9 & 81.8 & 18 & 66.6 & 0.89 & $0.47-1.68$ & 0.72 \\
\hline Shortness of breath & 5 & 45.5 & 15 & 55.5 & 0.61 & $0.16-2.18$ & 0.50 \\
\hline Thoracic pain & 4 & 36.3 & 4 & 18.5 & 3.14 & $0.62-15.98$ & 0.17 \\
\hline Weight loss & 6 & 54.5 & 20 & 74.0 & 0.36 & $0.08-1.61$ & 0.18 \\
\hline
\end{tabular}

OR: odds ratio, CI: confidence interval, OI: opportunistic infection, Tb: tuberculosis. 
Table 3 - Radiological findings from HIV-infected patients with pulmonary tuberculosis, stratified by CD4+ T-lymphocyte count (there may be more than one abnormality for the same patient).

\begin{tabular}{|c|c|c|c|c|c|c|}
\hline \multirow[b]{2}{*}{ Radiological findings } & \multicolumn{2}{|c|}{$\begin{array}{c}\mathrm{CD}^{+}>200 \\
\left(\mathrm{n}^{0}=11\right)\end{array}$} & \multicolumn{2}{|c|}{$\begin{array}{c}\mathrm{CD}^{+}<200 \\
\left(\mathrm{n}^{\mathrm{o}}=27\right) \\
\end{array}$} & \multirow[b]{2}{*}{$\mathrm{OR}$} & \multirow[b]{2}{*}{$\mathrm{p}$} \\
\hline & $\mathrm{n}^{0}$ & $\%$ & $\mathrm{n}^{0}$ & $\%$ & & \\
\hline post-primary abnormalities & 7 & 63.6 & 2 & 7.4 & 21.88 & 0.02 \\
\hline upper field cavitation & 6 & 54.5 & 2 & 7.4 & 21.87 & 0.001 \\
\hline upper field infiltration & 7 & 63.6 & - & - & & \\
\hline fibronodular opacity & 5 & 45.5 & - & - & & \\
\hline bronchogenic dissemination & 6 & 54.5 & - & - & & \\
\hline primary Tb alterations and others & 4 & 36.3 & 27 & 100 & - & - \\
\hline Lymphadenopathy ${ }^{*}$ & - & 12 & 44.4 & - & 0.39 & \\
\hline pleural infiltration & 1 & 9.1 & 6 & 22.2 & 0.28 & 0.69 \\
\hline upper or midfield infiltration & 2 & 18.2 & 8 & 29.6 & 0.52 & 0.23 \\
\hline diffused infiltration & 1 & 9.1 & 10 & 37.0 & 0.23 & - \\
\hline nodules & - & 1 & 3.7 & - & - & \\
\hline lobar consolidation & - & 1 & 3.7 & - & - & \\
\hline normal radiography & 1 & 9.1 & 4 & 14.8 & 0.57 & 1.00 \\
\hline
\end{tabular}

*Either hilar or mediastinal, OR: odds ratio, Tb: tuberculosis.

Table 4 - Results from bacilloscopy and culturing for Mycobacterium tuberculosis in airway material from HIV-infected patients with tuberculosis.

\begin{tabular}{lrrrrrr}
\hline Airway specimen & \multicolumn{2}{c}{ Positive bacilloscopy } & & \multicolumn{2}{c}{ Positive culture } \\
\cline { 2 - 3 } \cline { 6 - 7 } & $\mathrm{n}^{0}$ & $\%$ & & $\mathrm{n}^{0}$ & $\%$ \\
\hline Spontaneous sputum $\left(\mathrm{n}^{0}=33\right) *$ & 17 & 44.7 & & 30 & 78.9 \\
Induced sputum $\left(\mathrm{n}^{0}=6\right)$ & - & - & & 4 & 10.5 \\
Bronchoalveolar lavage $\left(\mathrm{n}^{0}=6\right)$ & 3 & 7.9 & & 4 & 10.5 \\
\hline Total & 20 & 52.6 & & 38 & 100 \\
\hline
\end{tabular}

*Five patients did not present spontaneous sputum.

Table 5 - Multivariate analysis of clinical and radiological parameters for HIV-infected patients with pulmonary tuberculosis, comparing patients with $\mathrm{CD}^{+}$T-lymphocyte count $>200$ cells $/ \mathrm{mm}^{3}$ with those with $\mathrm{CD} 4^{+}$cell count $<200$ cells $/ \mathrm{mm}^{3}$. Reference group is patients with $\mathrm{CD}^{+}$ T-lymphocyte count $<200$ cells $/ \mathrm{mm}^{3}$.

\begin{tabular}{lclr}
\hline Variable & Odds ratio & $95 \%$ CI & $\mathrm{p}$ \\
\hline Age & 0.20 & $0.02-1.98$ & 0.17 \\
Previous Tb treatment & 1.42 & $0.25-8.08$ & 0.70 \\
Tb as the first OI & 2.34 & $0.14-40.30$ & 0.56 \\
Alcohol use & 0.56 & $0.04-7.69$ & 0.66 \\
Post-primary pattern & 33.90 & $1.59-724.21$ & 0.02 \\
Thoracic pain & 6.23 & $0.36-106.57$ & 0.21 \\
Reported weight loss & 0.05 & $0.01-0.99$ & 0.05 \\
Positive AFB & 0.06 & $0.01-6.46$ & 0.18
\end{tabular}

CI: confidence interval, Tb: tuberculosis, OI: opportunistic infection, AFB: acid-fast bacillus.

\section{DISCUSSION}

The predominance of male and young patients in this study was similar to that found in other studies on tuberculosis coinfection conducted in Brazil ${ }^{11}{ }^{15}$. The mean age of our patients was lower than what was observed in South Africa, where $86.7 \%$ of the HIVinfected patients with pulmonary tuberculosis had a mean age of more than 30 years $^{19}$. In the present study, $73.6 \%$ of the patients were nonwhite. This finding differs from what has been found in other regions of Brazil ${ }^{11}$, where there is a preponderance of Caucasians among the patients with associated tuberculosis/HIV. Regarding education levels, our findings are comparable with the data from another Brazilian study ${ }^{10}$, in which the majority of the patients studied until the end of elementary school and a smaller proportion studied in high school or higher.

Considering the risk factors for HIV infection, the most (39.4\%) reported risk was heterosexual contact, which is in accordance with Brazilian epidemiology ${ }^{10}$.

The most common clinical findings in the study group were coughing and fever. High frequency of these clinical manifestations was also found in Ethiopia ${ }^{3}$ where more than $90 \%$ of the HIVinfected patients develop tuberculosis. In the present study, a third of the patients with pulmonary tuberculosis presented coughing for a period of less than three weeks, which is comparable with an African study conducted in an area of high prevalence of both tuberculosis and HIV infection ${ }^{2}$.

The reported weight loss was significantly lower in the group with a CD $4+\mathrm{T}$ lymphocyte count $>200$ cells $/ \mathrm{mm}^{3}$. This had been expected, taking into account that this symptom is frequently found in patients with an advanced stage of HIV infection, regardless of tuberculosis coinfection. These results are comparable with those found in another African study where weight loss greater than $10 \%$ was strongly correlated with CD4+ T-lymphocyte counts $<200$ cells $/ \mathrm{mm}^{3}$ for patients with both tuberculosis and HIV ${ }^{18}$.

The efficacy of sputum bacilloscopy for comparing HIVpositive and negative patients with tuberculosis is still a matter of debate. Some studies found a greater proportion of smear-negative tuberculosis in HIV-positive patients ${ }^{31522}$, whereas several authors did not find any difference in the efficacy of bacilloscopy between HIV-positive and negative patients 15192124 . According to Smith $e t$ $a l^{3}$, the level of CD4+ T lymphocytes and the absence of cavitation or any other abnormality in the parenchyma did not alter the possibility of positive bacilloscopy in HIV-positive patients. In our study, the proportion of positive AFB microscopy on spontaneous sputum of patients with a CD $4+>200$ cells $/ \mathrm{mm}^{3}$ was almost twice that of patients with lower CD4+ cell counts, although this difference was not statistically significant.

The radiological findings for tuberculosis in association with HIV infection, in our study, were similar to those presented in other studies ${ }^{1420}$, in which diffused or localized infiltration was more frequent, as well as hilar or mediastinal lymphadenopathy. Pleural infiltration, cavitation and normal radiography were the least common findings. However, studies conducted in Africa ${ }^{5} 19$ demonstrated greater frequency of cavitations in HIV-positive patients with tuberculosis. One explanation for this could be the high incidence of tuberculosis in that region ${ }^{6}$, where tuberculosis infection appears at earlier stages of HIV infection, when the immune system is relatively preserved ${ }^{817}$.

Pleural infiltration as a manifestation of tuberculosis in HIVpositive patients is more commonly reported in patients with a Tlymphocyte count of $\mathrm{CD} 4+^{+}>200$ cells $/ \mathrm{mm}^{3}$, which reflects a strong immune reaction in the pleura ${ }^{13}$. In contrast, we observed that the vast majority of cases with pleural infiltration in our study were found in patients with a T-lymphocyte count of $\mathrm{CD} 4+<200$ cells $/ \mathrm{mm}^{3}$. 
Normal radiography of the thorax may be present in 5\% to $10 \%$ of HIV-positive patients ${ }^{8}$ and in up to $20 \%$ of the patients with an advanced level of immunodepression?. It remains uncertain whether the absence of findings represents early stages of either primary disease or reactivation, or disease caused by intrathoracic adenopathy that has not been detected by simple radiographic examination ${ }^{20}$. Upon comparing different radiological patterns with the CD4+ T-lymphocyte count, an association between the radiological pattern of post-primary tuberculosis and a CD4+ Tlymphocyte count of $>200$ cells $/ \mathrm{mm}^{3}$ was found. All patients with CD4+ T-lymphocyte counts $<200$ cells $/ \mathrm{mm}^{3}$ presented radiological patterns that were different from the post-primary ones. These results are in accordance with other studies, where cavitation ${ }^{1920}$, post-primary or typical tuberculin radiological patterns ${ }^{9}$ were correlated with CD4+T-lymphocyte counts $>200$ cells $/ \mathrm{mm}^{3}$ and lymphadenopathy and atypical findings with lower counts ${ }^{1920}$.

Studies on the relationship between radiological patterns in tuberculosis cases and the time of infection, using molecular epidemiology, have suggested that the radiological appearance of tuberculosis is more related to host immunity than to whether the infection occurred recently or remotely ${ }^{712}$.

The limitations to the present study include the small specimen bank, the predominance of hospitalized patients and the exclusion of a considerable number of patients due to the rigid inclusion criteria. In addition, retrospective collection of data limits the availability and accuracy of the information.

In conclusion, patients with a CD4+ T-lymphocyte count > $200 \mathrm{cells} / \mathrm{mm}^{3}$ demonstrated a greater likelihood of presenting radiological patterns of post-primary tuberculosis and a smaller likelihood of reporting weight loss, in comparison with patients with a CD4+ T-lymphocyte count $<200$ cells $/ \mathrm{mm}^{3}$.

\section{REFERENCES}

1. Aderaye G, Bruchfeld J, Assefa G, Feleke D, Kallenius G, Baat M, Lindquist L. The relationship between disease pattern and disease burden by chest radiography, M. tuberculosis load, and HIV status in patients with pulmonary tuberculosis in Addis Ababa. Infection 32:333-338, 2004.

2. BandaHT, Harries AD, Welby S, Boeree MJ, Wirima JJ, Subramanyam VR, Maher D, Nunn PA. Prevalence of tuberculosis in TB suspects with short duration of cough. Transactions of the Royal Society of Tropical Medicine and Hygiene 92:161-163, 1998.

3. Bruchfeld J, Aderaye G, Palme IB, Bjorvatn B, Britton S, Feleke Y, Kallenius G, Lindquist L. Evaluation of outpatients with suspected pulmonary tuberculosis in a high HIV prevalence setting in Ethiopia: clinical, diagnostic and epidemiological characteristics. Scandinavian Journal of Infectious Diseases 34:331-337, 2002.

4. Centers for Diseases Control and Prevention. Revised surveillance case definition for HIV infection. Morbidity and Mortality Weekly Report 48 (RR-13):29-31, 1999.

5. Colebunders RL, Ryder RW, Nzilambi N, Dikilu K, Willame J, Kaboto M, Bagala N, Jeugmans J, Muepu K, Francis HL, Mann JM, Quinn TC, Piot P. HIV infection in patients with tuberculosis in Kinshasa, Zaire. American Review of Respiratory Disease 139:1082-1085, 1989.

6. Corbett EL, Watt CJ, Walker N, Maher D, Williams BG, Raviglione MC, Dye C. The growing burden of tuberculosis. Archives of Internal Medicine 163:1009-1021, 2003.
7. Geng E, Kreiswirth B, Burzynski J, Schluger NW. Clinical and radiographic correlates of primary and reactivation tuberculosis: a molecular epidemiology study. Journal of the American Medical Association 293:2740-2745, 2005.

8. Goodman PC. Tuberculosis and AIDS. Radiologic Clinics of North America 33:707$717,1995$.

9. Greenberg SD, Frager D, Suster B, Walker S, Stavropoulus C, Rothpearl A. Active tuberculosis in patients with AIDS: Spectrum of radiographic findings (including a normal appearance). Radiology 193:115-119, 1994.

10. Guimarães MDC. Estudo temporal das doenças associadas à Aids no Brasil, 1980-1999. Cadernos de Saúde Pública 16 (supl 1):1-21, 2000.

11. Henn L, Nagel F, Dal Pizzol F. Comparison between human immunodeficiency virus positive and negative patients with tuberculosis in Southern Brazil. Memórias do Instituto Oswaldo Cruz, 94:377-381, 1999.

12. Jones BE, Ryu R, Yang Z, Cave D, Pogoda JM, Otava M, Barnes PF. Chest radiographic findings in patients with tuberculosis with recent or remote infection. American Journal of Respiratory and Critical Care Medicine 155:1270-1277, 1997.

13. Jones BE, Young SMM, Antoniskis D, Davidson PT, Kramer F, Barnes PF. Relationship of the manifestations of tuberculosis to CD4+ cell counts in patients with human immunodeficiency virus infection. American Review of Respiratory Disease 148:1292-1297, 1993.

14. Kritski AL, Dalcolmo M, del Bianco R, Melo FF, Pinto WP, Schechther M, Castelo A. Associação tuberculose e infecção pelo HIV no Brasil. Boletin de la Oficina Sanitaria Panamericana 118:542-554, 1995.

15. Liberato IRO, Albuquerque MFM, Campelo AR, Melo HRL. Characteristics of pulmonary tuberculosis in HIV serum-positive and serum-negative patients in a Northeastern region of Brazil. Revista da Sociedade Brasileira de Medicina Tropical 37:46-50, 2004.

16. Ministério da Saúde. Manual de bacteriologia da tuberculose, $2^{\text {nd }}$ edition. Ministério da Saúde, Rio de Janeiro, 1994.

17. Ministério da Saúde. Diagnóstico da tuberculose. In: Ministério da Saúde. Controle da tuberculose: uma proposta de integração ensino-serviço, $5^{\text {th }}$ edition, Ministério da Saúde, Rio de Janeiro, p.63-96, 2002.

18. Mukadi Y, Perriens JH, St Louis ME, Brown C, Prignot J, Willame JC, Pouthier F, Kaboto M, Ryder RW, Portaels F, Piot P. Spectrum of immunodeficiency in HIV-1 infected patients with pulmonary tuberculosis in Zaire. The Lancet 342:143-146, 1993

19. Murray J, Sonnenberg P, Glynn J, Shearer S, Kambashi B, Godfrey-Faussett P. Human immunodeficiency virus and the outcome of treatment for new and recurrent pulmonary tuberculosis in African patients. American Journal of Respiratory and Critical Care Medicine 159:733-740, 1999.

20. Perlman DC, El-Sadr WM, Nelson ET, Matts JP, Telzak EE, Salomon N, Chirgwin K, Hafner R. Variation of chest radiographic patterns in pulmonary tuberculosis by degree of human immunodeficiency virus-related immunosuppression. Clinical Infectious Diseases 25:242-246, 1997.

21. Pitchenik AE, Rubinson HA. The radiographic appearance of tuberculosis in patients with the acquired immune deficiency syndrome (AIDS) and pre-AIDS. American Review of Respiratory Disease 131:393-396, 1985.

22. Pozniak AL, MacLeod GA, Ndlovu D, Ross E, Mahari M, Weinberg J. Clinical and chest radiographic features of tuberculosis associated with human immunodeficiency virus em Zimbabwe. American Journal of Respiratory and Critical Care Medicine 152:1558-1561, 1995.

23. Smith RL, Yew K, Berkowitz KA, Aranda CP. Factors affecting the yield of acid-fast sputum smears in patients with HIV and tuberculosis. Chest 106:684-686, 1994

24. Theurer CP, Hopewell PC, Elias D, Schecter GF, Ruthford GW, Chaisson RE. Human immunodeficiency virus infection in tuberculosis patients. The Journal of Infectious Diseases 162:8-12, 1990.

25. World Health Organization. Global tuberculosis control - surveillance, planning, financing. WHO Reports, 2005. http://www.who.int/tb/publications/global_ report/en/2006. 